\title{
Genotipagem do locus ABO (9q34.1) em doadores de sangue da região noroeste do Estado de São Paulo
}

\author{
Luiz C. Mattos ${ }^{1,2}$ \\ Fábio E. Sanchez $z^{2}$ \\ Juliana R. Cintra \\ Andréa B.C.F. Salles ${ }^{2}$ \\ Cláudia R. Bonini-Domingos ${ }^{3}$ \\ Haroldo W. Moreira ${ }^{4}$
}

\begin{abstract}
Os avanços da genética molecular permitiram o entendimento das bases moleculares do locus $\mathrm{ABO}$. Considerando sua importância como marcador genético e suas aplicações, o objetivo deste estudo foi verificar a distribuição dos genótipos ABO em uma amostra da população brasileira oriunda da região noroeste do Estado de São Paulo, Brasil. O DNA genômico extraído de 324 doadores de sangue (150 do gruро O; 118 do gruро $A ; 32$ do gruро B e 24 do gruро $A B$ ) foi amplificado por Polymerase Chain Reaction e digerido com enzimas de restrição. Quatorze genótipos foram identificados e as freqüencias relativas dos genes $\mathrm{O}^{1}, \mathrm{O}^{1 v}, \mathrm{O}^{2}$, A $e \mathrm{~B}$ foram estimadas em $44,6 \%, 16,9 \%, 4,1 \%, 25,3 \%$ e 9,1\%, respectivamente. Estes resultados demonstram que o locus $\mathrm{ABO}$ apresenta elevado polimorfismo quando analisado por métodos moleculares.

Rev.bras.hematol.hemoter., 2001, 23(1): 15-22
\end{abstract}

Palavras-chave: Genótipos $A B O$, genes $A B O$, doadores de sangue

\section{Introdução}

O maior sistema de aloantígenos expressos nos eritrócitos e em outros tecidos humanos constitui-se de quatro fenótipos definidos pelas combinações de dois antígenos carboidratos A e $\mathrm{B}$ e de dois anticorpos plasmáticos anti-A e anti-B. Os indivíduos com os fenótipos A, B e $\mathrm{AB}$ expressam glicosiltransferases específicas que convertem o antígeno $\mathrm{H}$ em $\mathrm{A}$ ou $\mathrm{B}$, mas aqueles com fenótipo $\mathrm{O}$ são incapazes de modificar a estrutura desse antígeno (1).
As glicosiltransferases que sintetizam os antígenos A e B são codificadas pelos genes que ocupam o locus $A B O$, os quais são herdados pelos princípios mendelianos (2) . O modelo com três genes $A, B$ e O proposto para explicar seu modo de herança foi confirmado com a clonagem e o seqüenciamento do locus $A B O$ no início dos anos noventa e a partir desses conhecimentos, as diferenças na seqüência de nucleotídeos dos genes tornaram-se conhecidas e passíveis de serem utilizadas na genotipagem de populações $(3,4)$.

\footnotetext{
1 - Departamento de Biologia Molecular. Faculdade de Medicina de São José do Rio Preto, SP

2 - Laboratório de Imunogenética Molecular. Hemocentro de São José do Rio Preto, SP.

3 - Departamento de Biologia. Ibilce - Unesp - São José do Rio Preto, SP.

4 - Departamento de Análises Clinicas. Faculdade de Ciências Farmacêuticas, Unesp, Araraquara, SP
}

Trabalho realizado no Laboratório de Imunogenética Molecular do Hemocentro de São José do Rio Preto, com o apoio financeiro da Bolsa de Auxílio à Pesquisa (BAP-Famerp 04123/98).

Correspondência para: Luiz Carlos de Mattos

Departamento de Biologia Molecular. Faculdade de Medicina de São José do Rio Preto Avenida Brigadeiro Faria Lima, 5416. 15090-000 São José do Rio Preto, SP

E-mail: lumattos@famerp.br 
Os genes $A$ e $B$ diferem em sete substituições de nucleotídeos localizadas nas posições 297, 526, 657, 703, 796, 803 e 930 e o gene $O^{1}$ é idêntico ao gene $A$, exceto pela deleção de uma base nitrogenada guanina na posição 261 do exon 6 (4). Essas diferenças contribuem para a troca de quatro aminoácidos nas posições 176, 235, 266 e 268 das transferases A e B e portanto, determinam suas especificidades (5).

Como as mutações criam ou abolem sítios de restrição, diferentes enzimas podem ser usadas na identificação desses genes e na definição dos vários genótipos do locus $A B O$. A deleção G261 cria um sítio de restrição para a enzima Kpn I, que permite diferenciar o gene $O^{1}$ dos genes $A$ e $B$; a substituição G703A cria outro sítio de clivagem para a enzima $A l u$ I, diferenciando o gene $B$ dos genes $O^{1}$ e $A$ e o gene $A$, por sua vez, pode ser identificado pelos sítios de restrição com as enzimas BssH II e Hpa II em torno das posições 526 e 703, respectivamente $(3,4)$.

Diferentes estudos identificaram, com base nessas alterações nucleotídicas, os genótipos $\mathrm{ABO}$ em materiais biológicos de interesse médico-legal e em sangue periférico, tendo sido possível a classificação das amostras analisadas em $A A, A O, B B, B O, A B$ e $O O(6,7,8,9,10)$.

A descrição de outros genes $O$ revelou que o polimorfismo do locus $A B O$ não estava restrito apenas aos genes $A, B$ e $O$. O gene $O^{2}$, sem a deleção G261, mas com as mesmas seqüências de nucleotídeos do gene $B$ na posição 526 e do gene $A$ nas posições 703, 796 e 803, foi encontrado em europeus com freqüência em torno de $3,7 \%(10,11,12)$. O gene $O^{1 v}$, embora apresente a deleção $\mathrm{G} 261$, difere do gene $O^{1}$ em sete nucleotídeos localizados nos exon 3, 4, 5, 6 e 7 e pode ser facilmente diferenciado com as enzimas BstU I, Kpn I, Mbo I e Dde I que reconhecem sítios de restrição nas posições 188, 261, 646 e 771 (13).

O objetivo deste trabalho foi verificar a distribuição dos genótipos $\mathrm{ABO}$ e estimar as freqüências relativas dos genes mais comuns em uma amostra da população brasileira oriunda região noroeste do Estado de São Paulo, Brasil.

\section{Material e métodos}

Após consentimento informado, foram coletados $5 \mathrm{ml}$ de sangue com EDTA de 324 doadores de sangue de ambos os sexos, caucasóides e não-caucasóides, com idades variando dos 18 aos 60 anos, provenientes da região noroeste do Estado de São Paulo. Os fenótipos eritrocitários do sistema $\mathrm{ABO}$ foram identificados por métodos de hemaglutinação padronizados em tubos (14), sendo o DNA genômico isolado dos leucócitos do sangue periférico por método salino (15).

Nosso protocolo de genotipagem consistiu de quatro reações de PCR, sendo que para a identificação dos genes $A, B, O^{1} \mathrm{e}$ $O^{2}$ foram realizadas três amplificações com os pares de primers fy-46/fy-57 para a PCR 1 , fy-43/fy-31 para a PCR 2 e fy-47/fy-29 para a PCR 3, enquanto os genes $O^{1}$ e $O^{1 v}$ foram diferenciados com os pares de primers fy-47/ fy-31 na PCR 4. A tabela 1 contém a seqüência dos primers utilizados nas quatro reações de PCR, realizadas a um volume final de $25 \mu \mathrm{L}$ e preparadas nas seguintes condições: TRIS-HCl $10 \mathrm{mM} ; \mathrm{MgCl}_{2}$ 1,5 mM; KCl $50 \mathrm{mM} ; 20 \mathrm{mM}$ de cada dNTP (dATP, dTTP, dCTP, dGTP), 20 pm de cada primer; 0,5 U de Taq polimerase; 5 ng de DNA genômico. Os segmentos que diferenciam os genes $A, B, O O^{P}$ e $O^{2}$ foram amplificados em 35 ciclos, sendo desnaturação a $94^{\circ} \mathrm{C}$ por 2 minutos, hibridização a $53^{\circ} \mathrm{C}$ por 1 minuto e extensão a $72^{\circ} \mathrm{C}$ por 1 minuto. Para os genes $O^{1}$ e $O^{1 v}$ foram realizados 35 ciclos, sendo desnaturação a $94^{\circ} \mathrm{C}$ por 1 minuto, hibridização a $52^{0^{\circ}} \mathrm{C}$ por 30 segundos e extensão a $72^{\circ} \mathrm{C}$ por 1 minuto.

Os produtos da amplificação foram submetidos à digestão com as seguintes enzimas: PCR 1 com Kpn I, PCR 2 com Nar I, PCR 3 com $A l u$ I e PCR 4 com Dde I, sendo os produtos da digestão analisados em gel de agarose a $2 \%$. A tabela 2 apresenta as características que diferenciam os genes do locus $\mathrm{ABO}$.

\section{Resultados}

O objetivo deste estudo foi investigar a distribuição do polimorfismo do locus $A B O$ numa amostra da população brasileira, 
Tabela 1. Reações de amplificação, seqüência de primers e tamanho dos fragmentos amplificados

\begin{tabular}{c|c|c|c}
\hline Reação & Primers & Seqüência & Fragmentos (pb) \\
\hline PCR 1 & fy-46 & 5'-GAATTCACTCGCCACTGCCTGGGTCTC-3' & 248*/249** \\
& fy-57 & 5'-GAATTCATGTGGGTGGCACCCTGCCA-3' & \\
PCR 2 & fy-43 & 5'-GGATCCAGGGGTGCACGGCCGGCGGC-3' & 467 \\
& fy-31 & 5'-GAAATCGCCCTCGTCCTT-3' & 621 \\
PCR 3 & fy-47 & 5'-TGCTGGAGGTGCGCGCCTAC-3' & \\
& fy-29 & 5'-CGTTCTGCTAAAACCAAG-3' & 278 \\
PCR 4 & fy-47 & 5'-TGCTGGAGGTGCGCGCCTAC-3' & \\
& fy-31 & 5'-GAAATCGCCCTCGTCCTT-3' & \\
\hline
\end{tabular}

* Para os genes $O^{1}$ e $O^{i v}$. ** Para os genes $O^{2}, A$ e $B$.

Tabela 2. Características que diferenciam os genes do locus $A B O$

\begin{tabular}{|c|c|c|c|c|c|c|}
\hline PCR & Exon & Mutação & Primers & Enzima & Genes & Fragmentos resultantes \\
\hline 1 & VI & G261- & $\begin{array}{l}f y-46 \\
\text { fy-57 }\end{array}$ & Kpn I & $O^{1} / O^{2}, A, B$ & $84+164 / 249$ \\
\hline 2 & VII & C526G & $\begin{array}{l}f y-43 \\
\text { fy-31 }\end{array}$ & Nar I & $O^{2}, B / O^{1}, A$ & $205+262 / 467$ \\
\hline 3 & VII & G703A & $\begin{array}{l}f y-47 \\
\text { fy-29 }\end{array}$ & $A l u \mathrm{I}$ & $B / O^{1}, O^{2}, A$ & $189+280+152 / 469+152$ \\
\hline 4 & VII & $\mathrm{C} 771 \mathrm{~T}$ & $\begin{array}{l}\text { fy- } 47 \\
\text { fy-31 }\end{array}$ & Dde I & $O^{1 v} / O^{1}$ & $169+87+22 / 191+87$ \\
\hline
\end{tabular}

Tabela 3. Distribuição percentual dos fenótipos e genótipos ABO identificados em 324 doadores de sangue da região noroeste do Estado de São Paulo, Brasil

\begin{tabular}{|c|c|c|c|c|c|}
\hline Fenótipos & $\mathbf{N}$ & $\%$ & Genótipos & $\mathbf{N}$ & $\%$ \\
\hline $\mathrm{O}$ & 150 & 46,3 & $\begin{array}{c}O^{1} O^{1} \\
O^{1} O^{1 v} \\
O^{1 v} O^{1 v} \\
O^{1} O^{2} \\
O^{1 v} O^{2} \\
O^{2} O^{2}\end{array}$ & $\begin{array}{c}66 \\
51 \\
12 \\
11 \\
8 \\
2\end{array}$ & $\begin{array}{c}20,3 \\
15,8 \\
3,8 \\
3,4 \\
2,4 \\
0,6\end{array}$ \\
\hline A & 118 & 36,4 & $\begin{array}{c}A A \\
A O^{1} \\
A O^{10} \\
A O^{2}\end{array}$ & $\begin{array}{c}22 \\
67 \\
25 \\
4\end{array}$ & $\begin{array}{c}6,8 \\
20,6 \\
7,8 \\
1,2\end{array}$ \\
\hline B & 32 & 9,8 & $\begin{array}{c}B B \\
B O^{1} \\
B O^{1 v}\end{array}$ & $\begin{array}{c}3 \\
28 \\
1\end{array}$ & $\begin{array}{l}0,9 \\
8,6 \\
0,3\end{array}$ \\
\hline $\mathrm{AB}$ & 24 & 7,5 & $A B$ & 24 & 7,5 \\
\hline Total & 324 & 100 & & 324 & 100 \\
\hline
\end{tabular}


constituída por doadores de sangue da região noroeste do Estado de São Paulo. Os fenótipos eritrocitários $\mathrm{ABO}$ dos 324 doadores de sangue foram determinados por métodos sorológicos de rotina e nenhum subgrupo raro foi encontrado; a distribuição fenotípica observada foi semelhante àquelas verificadas em outras amostras analisadas no Estado de São Paulo (16). A tabela 3 contém os valores percentuais dos fenótipos e genótipos identificados e permite estimar as freqüências relativas dos genes $O^{1}(44,6 \%), O^{1 v}(16,9 \%)$, $O^{2}(4,1 \%), A(25,3 \%)$ e $B(9,1 \%)$.

A digestão pela enzima $K p n$ I do segmento de 248 pares de bases amplificado na reação de PCR 1 identifica os genes $O^{1}$ e $O^{1 v^{5}}$. O fragmento original com 249 pares de bases não digerido por esta enzima é próprio dos genes $A, B$ e $O^{2}$, os quais não possuem a deleção G261. A segunda reação de PCR produz um fragmento com 467 pares de bases que ao ser digerido com a enzima Nar I, fornece dois fragmentos com 205 e 262 pares de bases,

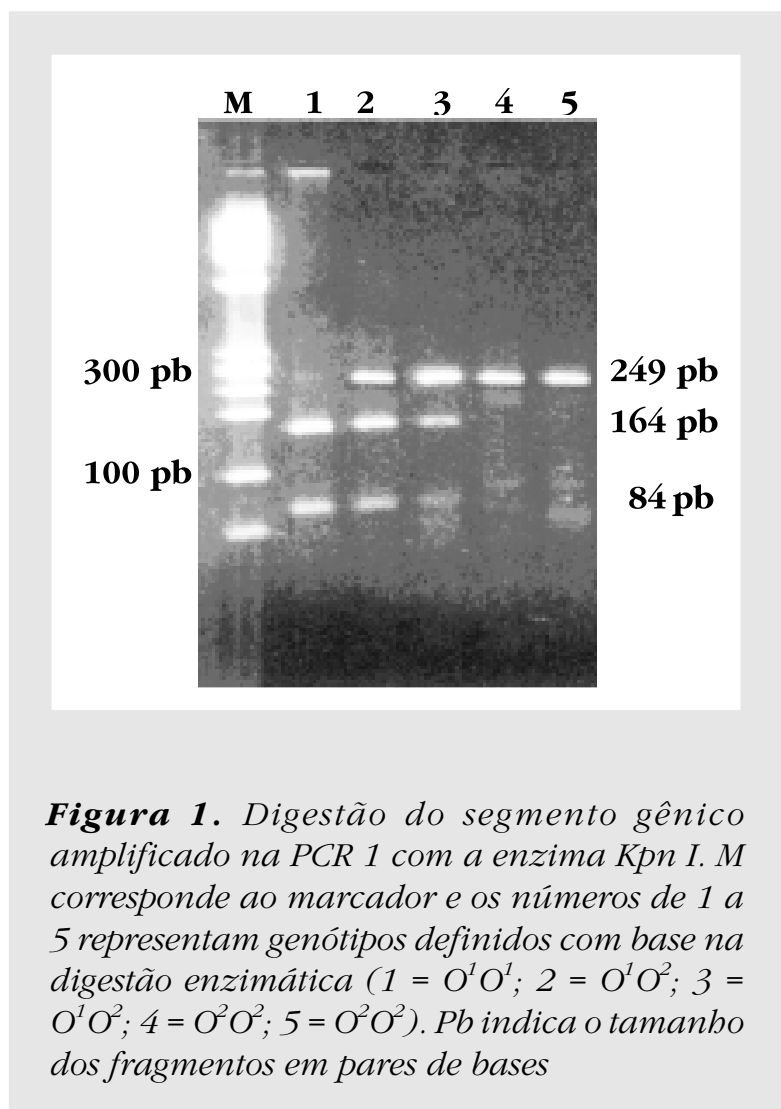

próprios dos genes $O^{2}$ e $B$. O fragmento não digerido corresponde aos genes $O_{2}^{1}, O^{1 v}$ e $A$. O gene $B$ é diferenciado do gene $O^{2}$ na terceira reação de amplificação, pois a enzima $A l u$ I digere o fragmento original de 621 pares de base em três fragmentos menores com 152, 189 e 280 pares de bases que definem o gene $B$ e em apenas dois fragmentos com 152 e 469 pares de base que identificam os genes $A, O^{1}$, $O^{1 v}$ e $O^{2}$. A quarta reação de amplificação produz um fragmento com 278 pares de bases que, quando digerido pela enzima Dde I, diferencia o gene $O^{1 v}$ do gene $O^{1}$. As figuras 1 , 2,3 e 4 ilustram os padrões de digestão enzimática dos segmentos amplificados nas quatro reações de PCR.

Os resultados da genotipagem de 324 doadores de sangue revelaram o elevado polimorfismo genotípico do locus $A B O$, não evidenciado pelos métodos sorológicos convencionais e todos os genótipos identificados foram concordantes com os fenótipos eritrocitários previamente definidos.

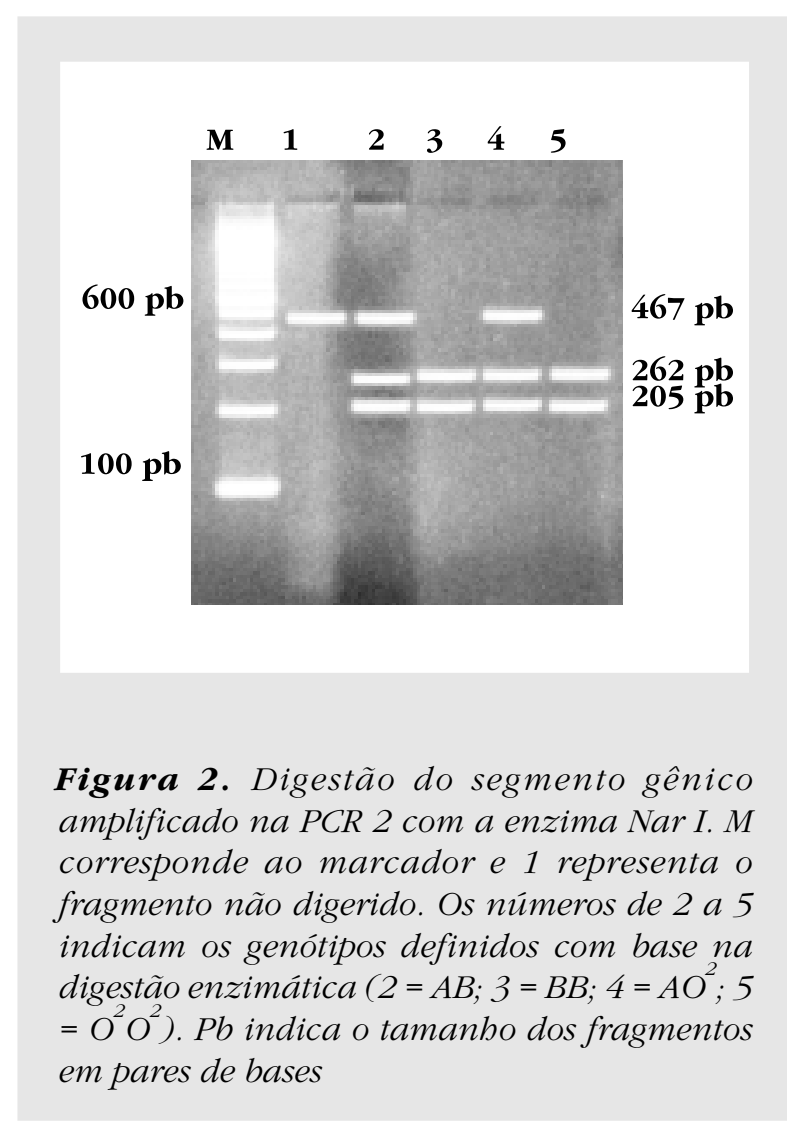




\section{Discussão e conclusões}

Os grupos sangüíneos $\mathrm{ABO}$ são tradicionalmente identificados por testes de hemaglutinação com anti-soros específicos, mas a definição precisa dos genótipos com essa metodologia requer estudos familiares, que podem ser de difícil realização e, muitas vezes, inconclusivos (2). Com o advento dos métodos moleculares, tornou-se possível analisar os genes que ocupam esse locus e determinar os genótipos a partir de amostras do DNA genômico $(3,4)$.

As técnicas de clonagem e seqüenciamento foram de grande utilidade na elucidação das bases moleculares do locus $A B O$ e revelaram que os genes $A, B$ e $O$ são similares e diferem em poucas substituições de nucleotídeos que alteram a seqüência de aminoácidos das transferases codificadas (3, 4, 5). Diferentes estudos e estratégias foram aplicados na determinação dos genótipos ABO em amostras de sangue periférico, manchas de sangue, gotas de saliva, sêmen, lágrima, swabs vaginais e outras amostras biológicas $(6,7,8,9,10)$.

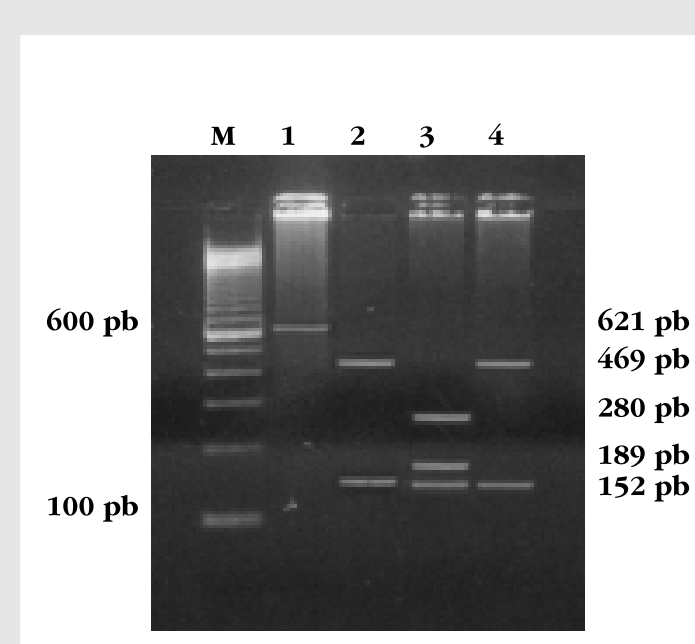

Figura 3. Digestão do segmento gênico amplificado na PCR 3 com a enzima Alu I. M indica o marcador e 1, o fragmento não digerido. Os números de 2 a 4 representam genótipos definidos com base na digestão enzimática $\left(2=A A ; 3=B B ; 4=A O^{1}\right)$. Pb indica o tamanbo dos fragmentos em pares de bases

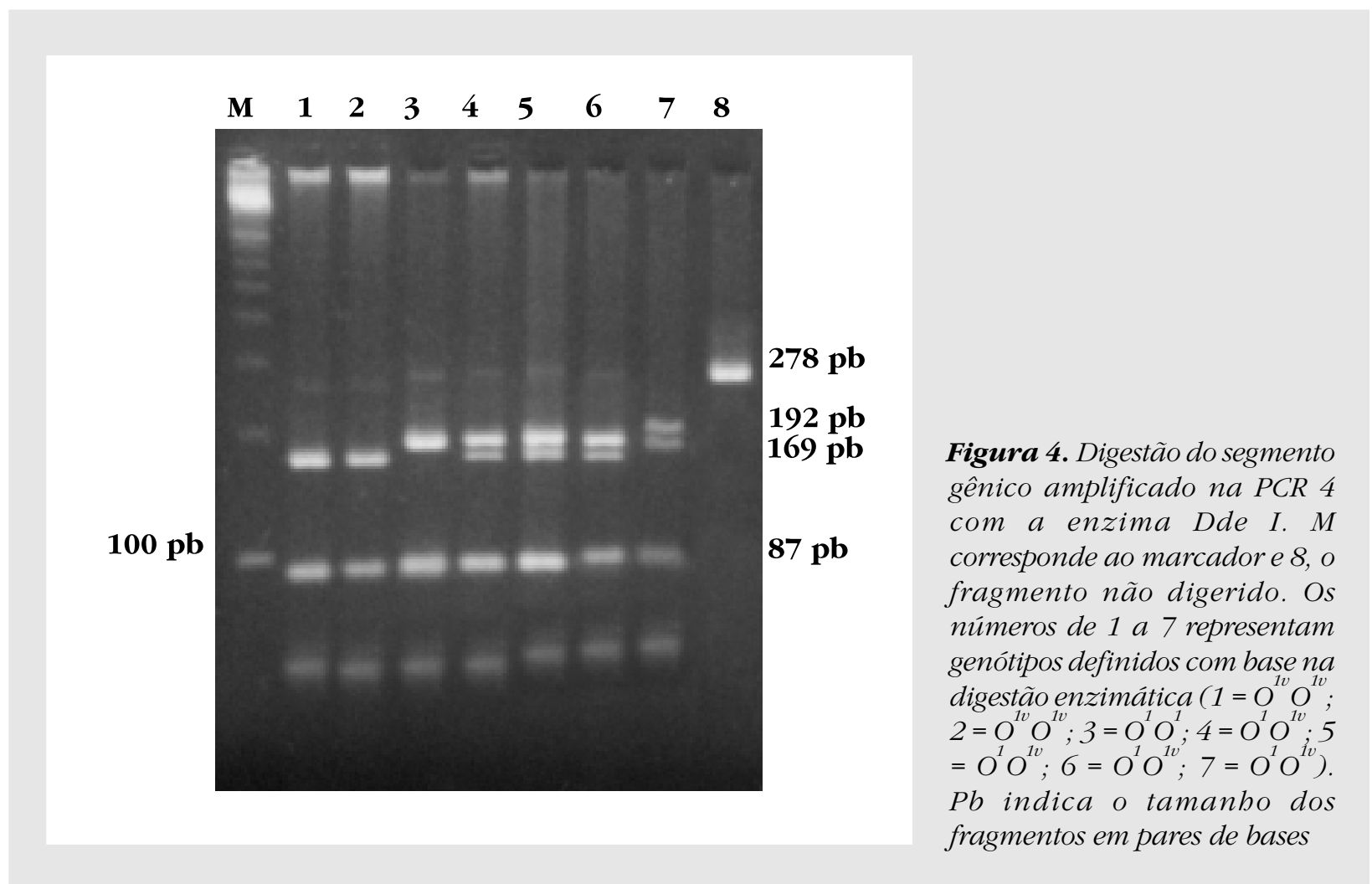


Neste estudo utilizamos o método PCR seguido da digestão com enzimas de restrição para determinar as freqüências dos genótipos do locus $A B O$ em 324 doadores de sangue de ambos os sexos, caucasóides e não caucasóides. As quatro reações de PCR e as subseqüentes digestões com as enzimas Kpn I, Nar I, Alu I e Dde I permitiram a caracterização dos genótipos com base nas alterações de nucleotídeos nas posições 261, 526, 703 e 771.

Entre 150 indivíduos do tipo $\mathrm{O}$, apenas dois não apresentaram a deleção G261 comum aos genes $O^{1}$, sendo que seus genótipos foram definidos como $\mathrm{O}^{2} \mathrm{O}^{2}$; onze doadores comportaram-se como heterozigotos pois apresentavam sempre um gene $O^{1}$ e outro $O^{2}$. Sessenta e três indivíduos mostraram-se como homozigotos quando analisados apenas com base na deleção G261, mas puderam ser diferenciados em homozigotos e heterozigotos para o gene $O^{1 v}$, ao serem analisados quanto ao sítio de restrição para a enzima Dde I; oito comportaram-se como heterozigotos $\mathrm{O}^{10} \mathrm{O}^{2}$. Esses resultados demonstraram claramente o polimorfismo dos genes $O$ do locus $A B O$, revelado anteriormente em diferentes grupos étnicos $(17,18,19,20,21,24)$ e nos permitiram estimar as freqüências relativas dos genes $O^{1}$, $\mathrm{O}^{1 v}$ e $\mathrm{O}^{2}$ em nosso meio.

A inatividade dos genes $O^{1}$ parece depender exclusivamente da deleção G261 no exon 6, visto que essa alteração cria um códon de terminação próximo ao nucleotídeo 347 e o RNAm transcrito é traduzido numa transferase anômala destituída do domínio catalítico (22). Por outro lado, a substituição G802A no exon 7 do gene $O^{2}$ parece ser o principal fator que compromete o efeito funcional da transferase codificada por esse gene (11).

Nos 118 indivíduos fenotipados como A foram detectados pelo menos um gene $A$ pela análise da substituição na posição 526 do exon 7. Entretanto, o fator determinante do polimorfismo dos genes $\mathrm{ABO}$ foram as combinações heterozigóticas com os genes $O^{1}$, $O^{1 v}$ e $O^{2}$, as quais puderam ser facilmente diferenciadas dos genótipos homozigotos $A A$.

O conhecimento prévio dos fenótipos eritrocitários facilita a definição dos genótipos que compõe o tipo A. Mesmo assim, alguns cuidados devem ser tomados na análise do polimorfismo do gene $A$ na posição 526, especialmente quando se utiliza DNA extraído de outras fontes que não o sangue e das quais não se têm informações sobre o fenótipo eritrocitário. A identificação do gene $A$ não pode ser direta, haja vista que em sua seqüência de nucleotídeos não foram descritos, até o momento, sítios de restrição exclusivos, estando portanto, sua determinação sempre ligada à exclusão de outros genes conhecidos (10, 22). Recentemente, foi descrito num indivíduo de fenótipo A, um gene $A$ com o mesmo nucleotídeo do gene $B$ na posição 526 , mas com os nucleotídeos 703 e 706 próprios do gene $A$ (23). Essa alteração, quando presente, pode levar à falsa interpretação dos genótipos, principalmente nas situações em que falta a informação sobre o fenótipo eritrocitário.

Entre os 32 indivíduos com fenótipo B analisados, verificamos maior freqüência de combinações heterozigotas com o gene $O^{1}$. Não foi encontrado nenhum caso com genótipo $B O^{2}$, o que pode ser explicado pela sua baixa freqüência na população (24). Outros estudos realizados em diferentes grupos raciais também não demonstraram a presença desse genótipo $(18,19)$.

Nos indivíduos fenotipados como $\mathrm{AB}$ foi possível detectar sempre um gene B com base no padrão de digestão da enzima Alu I. Essas observações são reforçadas pelos resultados obtidos em outros estudos (4, 6, 7, 25).

A metodologia molecular aplicada neste estudo mostra o elevado polimorfismo gênico e genotípico do locus ABO e reforça, portanto, sua importância como marcador genético. Além disso, embasam e justificam sua utilidade em estudos populacionais, filogenéticos e evolutivos, bem como para o seguimento de transplante de medula óssea alogênico $(26,27)$.

\section{Locus ABO (9q 34.1) genotyping in blood donors in the state of Sao Paulo, Brazil}

Luiz C. Mattos, Fábio E. Sanchez, Juliana R. Cintra, Andréa B.C.F. Salles, Cláudia R. BoniniDomingos, Haroldo W. Moreira 


\begin{abstract}
The advances of molecular genetics enabled us to understand the molecular basis of the ABO locus. Considering its importance as a genetic marker and its applications, the aim of this study was to verify the distribution of the ABO genotypes in a Brazilian population from the Northwest region of the São Paulo State, Brazil. The genomic DNA was extracted from three hundred and twenty four bealthy Brazilian blood donors (O 150;A 118; B 32 and $A B$ 24) and analyzed by PCR amplification followed by restriction enzyme digestion. Fourteen genotypes were identified and the relative frequencies of the $O^{1}$, $\mathrm{O}^{1 v}, \mathrm{O}^{2}, \mathrm{~A}$ and $\mathrm{B}$ genes were estimated at $44.6 \%$, $16.9 \%, 4.1 \%, 25.3 \%$ and $9.1 \%$, respectively. These results demonstrate that the ABO locus presents a high polymorphism as revealed by molecular analysis.

Rev.bras.hematol.hemoter., 2001, 23(1): 15-22
\end{abstract}

Key words: $A B O$ genotypes, $A B O$ genes, blood donors

\section{Referências Bibliográficas}

1. Watkins WM. Biochemistry and genetics of the ABO, Lewis and P blood group systems. Adv Hum Genet, 1980; 10: 1-136.

2. Daniels G. Human Blood Groups, Cambridge, 1995, 737p.

3. Yamamoto F, Marken J, Tsuji T, White T, Clausen H, Hakomori S. Cloning and characterization of DNA complementary to buman UDP-GalNAc: Fuc-alfa 1-2-alfa 13 GalNAc transferase (Histo-blood group A transferase) $m R N A$. J Biol Chem, 1990; 265 (2): 1146-1151.

4. Yamamoto F, Clausen H, White T, Marken $\mathrm{J}$, Hakomori S. Molecular genetic basis of the histo-blood group ABO system. Nature, 1990; 345: 229-233.

5. Yamamoto F, Hakomori S. Sugar-nucleotide donor specificity of histo-blood group $A$ and $B$ transferases is based on amino acid substitutions. J Biol Chem; 1990; 265(31): 19257-19262.

6. Chang JG, Lee LS, Chen PH. Rapid genotyping of the ABO blood group. Blood, 1992; 79(8): 2176-2177.
7. Lee JCI, Chang JG. ABO genotyping by polymerase chain reaction. J Foren Sci, 1992; 37(5): 1269-1275.

8. Crouse $\mathrm{C}$, Vincek V. Identification of $A B O$ alleles on forensic type specimens using rapid $A B O$ genotyping. BioTechnics, 1995; 18(3): 478-482.

9. Liechti-Gallati S, Neeser D. Efficient and reliable PCR based detection of the ABO blood group alleles: genotyping on stamps and other biological evidence samples. J Forens Sci, 1996; 41(4): 653-657.

10. Gassner C, Schmarda A, Nussbaumer W, Schonitzer D. ABO glycosyltransferase genotyping by polymerase chain reaction using sequence-specific primer. Blood, 1996; 88(5): 1852-1856.

11. Yamamoto F, McNeill PD, Yamamoto M, Hakomori S, Bromilow IM, Duguid JKM. Molecular genetic analysis of the ABO blood group system: 4. Another type of $O$ allele. Vox Sang, 1993; 64: 175-178.

12. Grunnett N, Steffelson R, Bennett EP, Clausen H. Evaluation of histo-blood group $A B O$ genotyping in a danish population: frequency of a novel $O$ allele defined as $O^{2}$. Vox Sang, 1994; 67: 210-215.

13. Olsson ML, Chester MA. Frequent occurrence of a variant $O 1$ gene at the blood group $A B O$ locus. Vox Sang, 1996; 70: 26-30.

14. Vengelen-Tyler V. Technical manual, $12^{\text {th }}$ edition, AABB, 1996.

15. Abdel-Rahman SZ. Isolation of DNA using salting-out procedure. J Biochem Toxicol, 1994; 9: 191-198.

16. Lima LMA, Callado MRM, Santos JA. Curso de Imunoematologia, Divisão Hemocentro, Faculdade de Medicina, Campus de Botucatu, Unesp, 1992.

17. Franco RF, Simões BP, Zago MA. Relative frequencies of the two $O$ alleles of the histoblood group ABH system in different racial groups. Vox Sang, 1995; 69: 50-52.

18. Yip SP, Yow CMN, Lewis WHP. DNA polymorphism at the ABO locus in the chinese population of Hong Kong. Hum Hered, 1995; 45: 266-271.

19. Villa A, Drago F, Mistò R, Morelati F, Poli F, Sirchia G. ABO genotyping in italian blood donors. Haematologica, 1996; 81: 492-496. 20. Olsson ML, Santos SEB, Guerreiro JF, Zago 
MA, Chester MA. Heterogeneity of the $O$ alleles at the $A B O$ blood group locus in amerindians. Vox Sang, 1998; 74: 46-50.

21. Johnson PH, Hopkinson DA. Detection of ABO blood group polymorphism by denaturing gradient gel electrophoresis. Hum Mol Genet, 1992; 1(5): 341-344.

22. Lutz, P; Dzik, WH. Molecular biology of the red cell blood group genes. Transfusion, 1992; 32(5): 467-486.

23. Stroncek DF, Konz R, Clay ME, Houchins JP, McCullouch J. Determination of $A B O$ glycosyltransferase genotypes by use of polymerase chain reaction and restriction enzymes. Transfusion, 1995; 35: 231-240.

24. Olsson ML, Chester MA. A rapid and simple $A B O$ genotype screening method using a novel $\mathrm{B} / \mathrm{O}^{2}$ versus $\mathrm{A} / \mathrm{O}^{2}$ discriminating nucleotide substitution at the ABO locus. Vox
Sang, 1995; 69: 242-247.

25. O'Keefe DS, Dobrovic A. A rapid and realible PCR method for genotyping the ABO blood group. Human Mutation, 1993; 2: 67-70

26. Zago MA, Tavella MH, Simões BP, Franco RF, Guerreiro JF, Santos SB. Racial beterogeneity of DNA polymorphisms linked to the $A$ and $O$ alleles of the $A B O$ blood group gene. Ann Hum Genetc, 1996; 60: 67-72

27. Mattos LC, Sanches FE, Carvalho-Salles AB, Ricci Jr O, Ruiz MA. Genotipagem do locus $\mathrm{ABO}$ aplicada ao seguimento de transplante de medula óssea alogênico. Anais do XXIV Congresso Brasileiro de Hematologia e Hemoterapia. Rio de Janeiro, 23 a 26 de maio de 2000.

Recebido: 18/12/00

Aceito: 10/03/01 